\title{
Detection of Leishmania braziliensis in human paraffin-embedded tissues from Tucumán, Argentina by polymerase chain reaction
}

\author{
Elizabeth Córdoba Lanús/ ${ }^{+}$, José Enrique Piñero*, Ana Cristina González* , Basilio \\ Valladares* , Mercedes Lizarralde de Grosso, 0 scar Daniel Salomón ${ }^{* *}$
}

\begin{abstract}
Instituto Superior de Entomología “Dr. Abraham Willink”, Facultad de Ciencias Naturales, Universidad Nacional de Tucumán, Tucumán, Argentina *Departamento de Parasitología, Facultad de Farmacia, Universidad de La Laguna, La Laguna, Tenerife,

España **Centro Nacional de Diagnóstico e Investigación en Endemoepidemias, ANLIS-Malbrán, Buenos Aires, Argentina
\end{abstract}

American cutaneous leishmaniasis (ACL) is an endemic disease in Northern Argentina. We applied the polymerase chain reaction (PCR) followed by a hybridization labelled probe to 21 paraffin embedded human skin biopsies, already analyzed histologically, from leishmaniasis endemic areas in the province of Tucumán, Argentina. We used primers previously designed to detect a Leishmania-specific 120-base-pair fragment of kinetoplast DNA minicircle, other two primer pairs that amplify kDNA minicircles belonging to the L. braziliensis and L. mexicana complexes respectively, and specific oligonucleotide primers to detect $\mathrm{L}$. (V.) braziliensis which amplify the sequence of the ribosomal protein L-14 of this species. The PCR-hybridization showed a sensitivity of $90.5 \%$ when compared to the histopathology test which was $61.9 \%$. Five of the total samples analyzed were positive for the $\mathrm{L}$. braziliensis complex whilst none was positive for the $\mathrm{L}$. mexicana complex. The specific primers for $\mathrm{L}$. (V.) braziliensis detected the parasite in four samples. These results are consistent with those reported for close endemic areas and demonstrate that the causative agent of human leishmaniasis in the analyzed cases was L. (V.) braziliensis. PCR should be used as a diagnostic tool for tegumentary leishmaniasis, especially in the mucosal form, and as a valuable technique for the identification of the Leishmania species that causes the disease in certain areas.

Key words: Leishmania (V.) braziliensis - diagnosis - polymerase chain reaction - Argentina

American tegumentary leishmaniasis (cutaneous and mucocutaneous) has been endemic in Argentina since 1916 (Mazza 1926). In the Northern provinces of the country, outbreaks were identified in 1985/1987, 1997/1998, and 2002. In Tucumán province, between 1991 and 1996, 232 leishmaniasis cases were reported (Marcolongo et al. 1993, Yadón 1997, Villalonga 1998).

In the Americas the causal agents of this pathology are the mexicana complex species: Leishmania (L.) mexicana, $L$. (L.) amazonensis, and $L .(L$.) venezuelensis; the subgenera Viannia braziliensis complex: L. (V.) braziliensis, $L$. (V.) peruviana, and $L$. (V.) lainsoni); and the guyanensis complex: $L$. (V.) panamensis and $L$. (V.) guyanensis. The disease is characterized by cutaneous lesions which may develop to metastatic mucosal sores. It is known that $L$. (V.) braziliensis is the causal agent of cutaneous and mucocutaneous leishmaniasis, and in some immune compromised cases it may present visceral manifestations.

The clinical and epidemiological pattern of the human cases observed in Tucumán were related to leishmaniasis due to $L$. (V.) braziliensis as described in other outbreaks

\footnotetext{
Financial support: Conicet

${ }^{+}$Corresponding author present address: Unidad de Investigación, Hospital Universitario Nuestra Señora de la Candelaria, Carretera del Rosario s/n, (38010), Santa Cruz de Tenerife, España

E-mail: elicordoba@hotmail.com

Received 14 June 2004

Accepted 24 February 2005
}

in the country (Sosa-Estani et al. 1998). At present, the characterization of parasites from human patients in Tucumán has not been possible. Studies from epidemic outbreaks in nearby provinces within Argentina, indicate that the parasites belong to the L. braziliensis complex (Campanini et al. 1993, Cuba et al. 1996, Sosa-Estani et al. 1998). The presence of $L$. (L.) amazonensis (L. mexicana complex) by isoenzymatic analysis has also been reported in the Chaco region, Argentina (Frank et al. 2000).

The most common diagnostic method for cutaneous leishmaniasis used in Argentina is the smear - histopathology exam in combination with clinical and epidemiological data. Mucocutaneous leishmaniasis generally requires a complementary test because of the scarcity of parasites in the lesions.

The polymerase chain reaction technique (PCR) has been successfully employed in the detection of specific sequences of pathogenic agents (Erlich 1991). At present this technique is an adequate method for the leishmaniasis diagnosis, showing a high sensitivity when compared to traditional tests (Rodgers et al. 1990, 1994, De Bruijn \& Barker 1992, De Bruyin et al. 1993, Lopez et al. 1993a, b, Meredith et al. 1993, Piarroux et al. 1994). The sensitivity of the laboratory diagnosis increases significantly when PCR is combined with Southern blotting (Andresen et al. 1996).

In the present study we used PCR and Southern blotting for the detection of Leishmania spp. and identification of the parasite from skin biopsies, histologically examined, of human patients from an endemic area of Tucumán province, Argentina. 


\section{MATERIALS AND METHODS}

Samples - In this study we used 22 paraffin-embedded skin biopsies from endemic areas of leishmaniasis in the province of Tucumán, kindly donated by the Pathologic Anatomy Service of the Angel C Padilla Hospital (Tucumán, Argentina). Twenty one of the samples had a clinical diagnosis for leishmaniasis and the histopathology test was positive for 13 of them and negative for the rest (Table I). The only sample with a nonleishmanial clinical diagnosis and a negative histopathology result was that used as a negative control.

DNA extraction - For each sample five to seven $5 \mu \mathrm{m}$ sections of paraffin-embedded tissue were placed in a tube. The samples were washed with xilene, incubated for $30 \mathrm{~min}$ at $37^{\circ} \mathrm{C}$, centrifuged at $13,000 \mathrm{rpm}$ for $5 \mathrm{~min}$ and the supernatant discarded. The washing procedure was repeated three times. Then two washes with ethanol 100\% were performed followed by two final washes with PBS ( $\mathrm{NaCl} 0.14 \mathrm{M}, \mathrm{KCl} 2.68 \mathrm{mM}, \mathrm{Na}_{2} \mathrm{HPO}_{4} 0.01 \mathrm{M}, \mathrm{KH}_{2} \mathrm{PO}_{4}$ $1.76 \mathrm{mM}, \mathrm{pH}$ 7.4). The resulting pellet was resuspended in a $100 \mu \mathrm{l}$ of Proteinase-K lysis buffer (Tris- $\mathrm{HCl} 10 \mathrm{mM}$, pH 8.5 , EDTA $10 \mathrm{mM}$ and $4 \mu \mathrm{l}$ of Proteinase- $\mathrm{K}(20 \mathrm{mg} / \mathrm{ml})$. The samples were incubated at $60^{\circ} \mathrm{C}$ for $2 \mathrm{~h}$. Then the enzyme was inactivated for $5 \mathrm{~min}$ at $95^{\circ} \mathrm{C}$ and the samples rapidly centrifuged. Two $\mu 1$ of the supernatants of each sample were used for the PCR reaction (modified from Wright \& Manos 1990).

PCR procedure - The primers used to detect Leishmania spp. were previously designed (Fernandes et al. 1994). Briefly, the PCR reaction mixture ( $50 \mu$ total volume) consisted of PCR buffer $1 \mathrm{X}$ (10mM Tris-HCl, $\mathrm{pH} 8.3,50 \mathrm{mM}$ $\mathrm{KCl}, 1.5 \mathrm{mM} \mathrm{MgCl}_{2}$ ) (Perkin-Elmer), $2.5 \mathrm{U} / \mu \mathrm{l}$ of Taq DNA polymerase (Perkin-Elmer), $200 \mu \mathrm{M}$ of each deoxynucleoside triphosphate (dNTPs) (Pharmacia), 15 pmol of each primer, and $2 \mu$ of the DNA sample. In this reaction DNA amplification was performed for a first cycle at $94^{\circ} \mathrm{C}$ for 5 min of incubation, 30 cycles at $94^{\circ} \mathrm{C}$ for $30 \mathrm{~s}, 50^{\circ} \mathrm{C}$ for $30 \mathrm{~s}$ and $72^{\circ} \mathrm{C}$ for $30 \mathrm{~s}$ with a final extension cycle of $10 \mathrm{~min}$ at $72^{\circ} \mathrm{C}$. In the case of specific DNA amplification of the $L$. braziliensis and L. mexicana complexes we used the oligonucleotide primers B1/B2 (De Bruijn \& Barker 1992) and M1/M2 (Eresh et al. 1994) respectively. The reaction mixture consisted of $5 \mu 1$ of PCR buffer (1X), $8 \mu 1$ of dNTPs, $0.5 \mu \mathrm{l}$ of each primer $(20 \mathrm{pmol} / \mu \mathrm{l}), 2 \mu \mathrm{l}$ de DNA $(10 \mathrm{ng} / \mu \mathrm{l})$, $0.5 \mu 1$ de Taq DNA polymerase $(2.5 \mathrm{U} / \mu \mathrm{l})$ and $33.5 \mu \mathrm{l}$ of ultrapure water. DNA amplification was performed for 35 cycles using previously established conditions (De Bruijn $\&$ Barker 1992, Eresh et al. 1994). For the detection of $L$. (V.) braziliensis DNA we used the primers L14-A/L14-C (Alonso 1999). The PCR reaction mixture (50 $\mu$ l total volume) consisted of PCR buffer $1 \mathrm{X}$ (10mM Tris-HCl, $\mathrm{pH} 8.3$, $50 \mathrm{mM} \mathrm{KCl}, 1.5 \mathrm{mM} \mathrm{MgCl} 2$ ) (Perkin-Elmer), $2.5 \mathrm{U} / \mu \mathrm{l}$ of $\mathrm{Taq}$ DNA polymerase (Perkin-Elmer), $200 \mu \mathrm{M}$ of each deoxynucleoside triphosphate (dNTPs) (Pharmacia), 15 pmol of each primer, and $2 \mu 1$ of the DNA sample. DNA amplification was performed by a first cycle at $94^{\circ} \mathrm{C}$ for 3 min of incubation, followed by 30 cycles at $94^{\circ} \mathrm{C}$ for $1 \mathrm{~min}$, $58^{\circ} \mathrm{C}$ for $1 \mathrm{~min}$ and $72^{\circ} \mathrm{C}$ for $1: 30 \mathrm{~min}$, with a final extension cycle at $72^{\circ} \mathrm{C}$ for $10 \mathrm{~min}$. Negative (no DNA and $L$. $(L$.) tropica DNA) and positive $[L$. (V.) braziliensis or $L$. (L.) amazonensis DNA] controls were used.

PCR products were analyzed on a $1.5 \%$ agarose gel, stained with ethidium bromide and visualized under UV light. All products were transferred to a nylon membrane using a southern blot procedure according to standard conditions (Sambrook et al. 1989). Two PCR amplified minicircle kDNA fragments from $L$. (V.) braziliensis strain (MHOM/PE/95/LQ2) and L. (L.) amazonensis strain (MHOM/77/LTB0016) were used as probes in different reactions. The amplified products were isolated from an agarose gel and purified by the Quiaex II gel extraction Kit (Quiagen). Twenty five ng of each purified fragment were labelled with digoxigenin coupled to dUTP (deoxyuracile triphosphate) using the DIG DNA Labeling Kit (Boehringer Mannhein). The blot was prehibrydized at $68^{\circ} \mathrm{C}$ for $2 \mathrm{~h}$ in SSC 5X (sodium chloride $0.15 \mathrm{M}$, trisodium citrate 0.015 M), sodium dodecyl sulphate (SDS) $0.02 \%$, N-lauroylsarcosine, blocking reagent $2 \%$ (Roche). Hybridization with the specific labelled probe $L$. (V.) braziliensis or $L$. (L.) amazonensis ( $25 \mathrm{ng}$ ), depending on the reaction, was performed at $68^{\circ} \mathrm{C}$ overnight. Washing conditions were $2 \times 5 \mathrm{~min}$ in SSC $2 \mathrm{X}$, SDS $0.1 \%$ at room temperature and $2 \times 15 \mathrm{~min}$ in SSC $0.1 \mathrm{X}$, SDS $0.1 \%$ at $68^{\circ} \mathrm{C}$. The hybridized products were immunodetected with anti-digoxigeninAP, Fag fragments and then visualized with the colorimetric substrates NBT/BCIP using the DIG Nucleic Acid Detection Kit (Roche).

\section{RESULTS}

From all of the samples with a clinical diagnosis of leishmaniasis DNA amplification with genus-specific primers was positive in 19 of them. The amplified Leishmaniaspecific fragment (120 bp) corresponds to the amplification of a minicircle sequence of the kDNA. These results were confirmed by the Southern blot-hybridization of the PCR products with the specific $L$. (V.) braziliensis probe (Fig. 1).

The entire samples positive for cutaneous leishmaniasis by histopathology were also positive with the PCR hybridization combined technique. Leishmania DNA was detected in 6 of the 8 samples that showed a negative diagnosis of leishmaniasis when assessed histopathology. It is noteworthy that one of these 6 samples belonged to a clinically cured patient (Table).

The only sample with nonleishmanial clinical features, used as a negative control, showed negative results when analysed by both methods, i.e., histopathology and PCRhybridization.

Overall PCR-hybridization showed a sensitivity of $90.5 \%$, whilst for the histopathology test was $61.9 \%$.

The second step was to determine more precisely the parasite present in the 19 positive samples for Leishmania spp.

Firstly, we performed a PCR using primers specific for the L. braziliensis and L. mexicana complexes followed by a hybridization assay. The amplified products obtained showed a $760 \mathrm{bp}$ fragment in the positive samples in both cases. From all the samples analyzed we were able to de- 
tect in 5 of them the parasite as belonging to the $L$. braziliensis complex (Fig. 2). We did not detect any $L$. mexicana complex parasite in the samples.

Secondly, the 19 samples positive by the PCR Leishmania specific were analysed with a PCR specific for the species L. (V.) braziliensis. A 160 bp fragment was amplified in 4 of the samples. This result was confirmed with a
Southern blot and hybridization with a specific probe for L. (V.) braziliensis.

There was only one positive sample detected by both PCR-hybridization experiments, i.e., the one using B1/B2 specific primers for the L. braziliensis complex and the one using L14-A/L14-C specific primers for the species $L$. (V.) braziliensis.

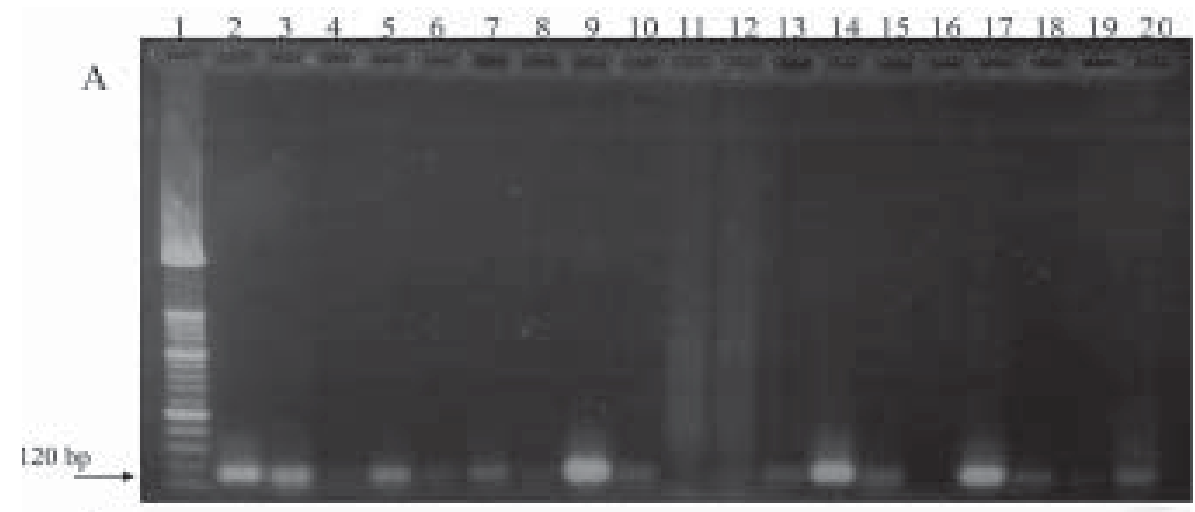

B

Fig. 1A: polymerase chain reaction amplification of paraffin-embedded biopsies using Leishmania genus-specific primers; B: hybridization with a $L$. (V.) braziliensis specific probe. 1: 100 bp molecular weight marker; 2: positive control; 3: L66239; 4: L69252; 5: L1085; 6: L1299; 7: L1418; 8: L1532; 9: L1823; 10: L0413; 11: L1524; 12: L0528; 13: L0032; 14: L0554; 15: L0592; 16: L1957; 17: L1584; 18: L1857; 19: L0349; 20: L0679

TABLE I

Results of the histopathology and polymerase chain reaction (PCR)-hybridization analysis of human paraffin-embedded biopsies from Tucumán-Argentina

\begin{tabular}{|c|c|c|c|c|c|c|}
\hline & Samples & Lesion & Histopathology & $\begin{array}{l}\text { PCR- hybrid } \\
\text { Leishmania } \\
\text { spp. }\end{array}$ & $\begin{array}{l}\text { PCR- hybrid } \\
\text { L. braziliensis } \\
\text { complex }\end{array}$ & $\begin{array}{c}\text { PCR- hybrid } \\
\text { L. (V.) } \\
\text { braziliensis }\end{array}$ \\
\hline 1 & L-66239 & $*$ & + & + & - & + \\
\hline 2 & L-69252 & $*$ & + & + & - & - \\
\hline 3 & L-1085 & Cutaneous & + & + & + & - \\
\hline 4 & L-1299 & $*$ & + & + & - & - \\
\hline 5 & L-1418 & Cutaneous & + & + & - & - \\
\hline 6 & L-1532 & Cutaneous & + & + & - & - \\
\hline 7 & L-1823 & Cutaneous & + & + & + & - \\
\hline 8 & L-0413 ${ }^{a}$ & Cutaneous & - & + & - & - \\
\hline 9 & L-0528 & $*$ & - & + & - & - \\
\hline 10 & L-0032 & Mucocutaneous & + & + & - & - \\
\hline 11 & L-0554 & Cutaneous & - & + & - & + \\
\hline 12 & L-0592 & Cutaneous & + & + & + & + \\
\hline 13 & L-1524 & Cutaneous & - & - & ND & ND \\
\hline 14 & L-1584 & Cutaneous & + & + & - & - \\
\hline 15 & L-1857 & Mucocutaneous & - & + & + & - \\
\hline 16 & L-0349 & Cutaneous & - & + & - & + \\
\hline 17 & L-0679 & Cutaneous & + & + & - & - \\
\hline 18 & L-0805 & Mucocutaneous & + & + & + & - \\
\hline 19 & L-1957 & Cutaneous & - & - & ND & ND \\
\hline 20 & L-2195a & Cutaneous & - & + & - & - \\
\hline 21 & L-2195b & $*$ & + & + & - & - \\
\hline
\end{tabular}

* The clinical data supplied by the Anatomy Pathologic Service (Hospital Angel C Padilla, Tucumán, Argentina) of these patients did not show whether the lesion was cutaneous or mucocutaneous; $a$ : sample of a patient after complete treatment of the disease; ND: not done. 


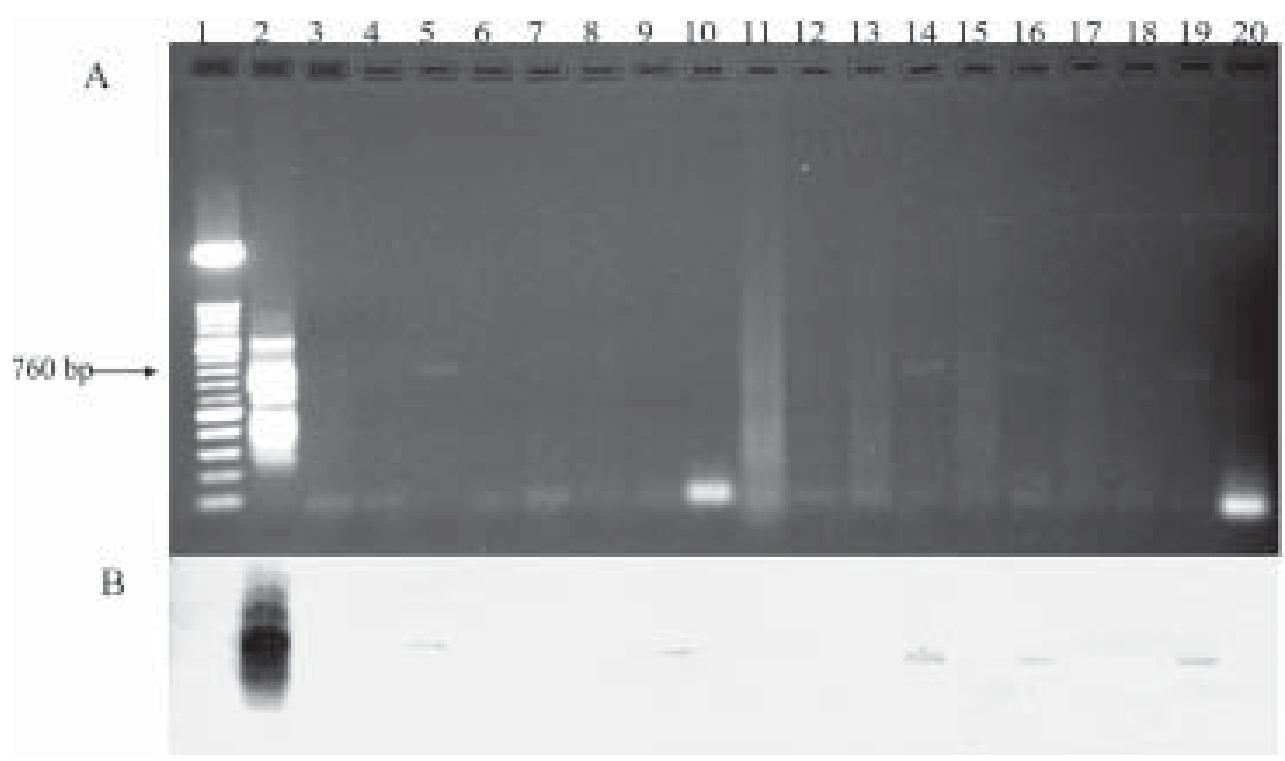

Fig. 2A: polymerase chain reaction amplification of paraffin-embedded biopsies using Leishmania braziliensis complex-specific primers; B: hybridization with a $L$. (V.) braziliensis specific probe. 1: 100 bp molecular weight marker; 2: positive control; 3: L66239; 4: L69252; 5: L1085; 6: L1299; 7: L1418; 8: L1532; 9: L1823; 10: L1957; 11: L0528; 12: L0032; 13: L0554; 14: L0592; 15: L1584; 16: L1857; 17: L0349; 18: L0679; 19: L0805; 20: L2195

\section{DISCUSSION}

This study reveals that $L$. (V.) braziliensis was the causal agent of leishmaniasis in the human samples analyzed using a PCR-hybridization assay.

The results presented here demonstrate that the leishmanial etiology was established in $61.9 \%$ by the conventional method and in $90.5 \%$ by PCR-hybridization. No false positive results were obtained. Laskay et al. (1995), using oligonucleotide primers $13 \mathrm{~A}$ and $13 \mathrm{~B}$ were able to detect L. aethiopica in paraffin-embedded tissue, in 7 out of the 22 cases where the conventional methods failed. They proposed the PCR as a valid diagnostic method for leishmaniasis, especially for chronic cases of the pathology. Furthermore, Medeiros et al. (2002) using the same primers found positivity in $81.5 \%$ of the examined samples by PCR, with a specificity of $100 \%$, while the histological test was positive in 50\% of the cases. Safei et al. (2002) found a sensitivity of $92 \%$ in the diagnosis of cutaneous leishmaniasis in paraffin-embedded biopsies using PCR, and a specificity of $100 \%$.

The PCR combined with Southern blotting can increment the sensitivity of the method. Andresen et al. (1996) reached a $93 \%$ of positives using this combination when compared to the results obtained by PCR when used alone $(86 \%)$ in contrast with the sensitivity detected by histopathology $(76 \%)$.

Five of the total samples analysed by the complex specific primers B1/B2 (De Bruijn \& Barker 1992) were positive for the L. braziliensis complex.

Furthermore, the PCR using the primers L14-A and L14-C (Alonso 1999) specific for $L$. (V.) braziliensis, which amplify the sequence of the ribosomal protein L14 of this species (Gonzalez et al. 2004), detected the parasite in 4 samples, only one of them was also amplified by the PCR specific for the L. braziliensis complex.

The oligonucleotides B1/B2 used in this assay are capable of detecting $1 \mathrm{fg}$ of purified DNA, equivalent to about $1000 \mathrm{kDNA}$ minicircles of $760 \mathrm{bp}$. This method was evaluated using a diversity of crude DNA samples: human biopsies and lymph aspirates; sand flies samples and biopsies from wild animals (De Bruijn \& Barker 1992). De Bruijn et al. (1993) in a study performed in Cali, Colombia, using this method obtained $84.6 \%$ sensitivity for PCR compared to traditional methods.

We consider it possible that the oligonucleotide primers B1/B2 may not detect DNA of all the species belonging to the complex or its variants. These primers were design based on a fragment of $208 \mathrm{bp}$ of the minicircle of kDNA common to the species $L$. (V.) braziliensis, $L$. (V.) guyanensis, $L$. (V.) peruviana, and $L$. (V.) panamensis. These four species were considered integrants of the complex L. braziliensis. Moreover the common DNA sequences of $L$. (V.) braziliensis, $L$. (L.) amazonensis and $L$. (L.) major are also between this conserved region.

At present the L. braziliensis complex is formed by the species: L. (V.) braziliensis, L. (V.) peruviana, L. (V.) colombiensis, $L$. (V.) naiffi, $L$. (V.) lainsoni, and $L$. (V.) shawi, being the species $L$. (V.) guyanensis and $L$. (V.) panamensis included in the complex L. guyanensis. Taking this into account the primers B1/B2 can probably not detect the DNA of all the species included in the $L$. braziliensis complex.

The use of primers B1/B2 has not previously been reported in formalin fixed and paraffin embedded tissues samples. However, because of the results obtained by the PCR genus-specific we can exclude the possibility of PCR inhibition. The latter detected Leishmania DNA in all the histopathologic positive samples for cutaneous leishmaniasis. Furthermore, the negative control gave a negative 
result in both PCR assays.

The results obtained by the PCR specific for $L$. (V.) braziliensis did not completely match those obtained by the specific primers of the L. braziliensis complex. This could be attributed to the fact that the primers L14-A/L14C could amplify DNA fragments of only certain strains of L. (V.) braziliensis. PCR inhibition is discarded for the same reason as cited above for the primers B1/B2. Primers L14-A/L14-C were design based on the reference strains L. (V.) braziliensis (MHOM/PE/95/LQ-8) from Cuzco, Peru, and LR537, LR538, LR539, LR548, LR557, LR560 which were isolated from areas close to Cuzco. These oligonucleotides were also tested on other species, $L$. (L.) infantum, L. (L.) mexicana, L. (L.) chagasi, L. (L.) forattini, and with Trypanosoma cruzi, all showing a negative result (Alonso 1999).

The results of this study are reinforced by the clinical and epidemiological pattern of the human cases observed in Tucumán, which were related to leishmaniasis caused by $L$. (V.) braziliensis as observed in other outbreaks in the country (Sosa-Estani et al. 1998).

Diverse molecular and biological methods have proved that the outbreak that occurred in the north-western province of Salta in 1985 was caused by L. (V.) braziliensis, although the zymodeme analysis showed a close relationship with L. (V.) guyanensis and L. (V.) panamensis (Segura et al 2000). Furthermore, L. (V.) braziliensis was detected in patients from Santiago del Estero province (next to Tucumán) by monoclonal antibodies and isoenzyme techniques (Torno-Cafasso et al. 1995, Cuba-Cuba et al. 1996). However, in the Chaco region (north-eastern Argentina) the specie L. (L.) amazonensis was detected (Frank et al. 2000).

In summary, the results presented here demonstrate that the causative agent of human leishmaniasis in the analysed cases using PCR-hybridization is $L$. $(V$.) braziliensis. Finally, this study also suggests the presence of other species of the parasite belonging to the $L$. braziliensis complex, or other strains of L. (V.) braziliensis that were impossible to detect.

\section{ACKNOWLEDGEMENTS}

To Dr S Molina (Avellaneda Hospital) and Dr Ortiz Mayor (Angel C Padilla Hospital) for their collaboration. To Dr JM Padrón for suggestions and critical comments on the manuscript.

\section{REFERENCES}

Alonso V 1999. Aplicación de RADP para el Diagnóstico y Estudio Molecular de Leishmania braziliensis, Ph D Thesis, Universidad de La Laguna, Tenerife, España.

Andresen K, Gaafar A, El-Hassan AM, Dafalla M, Theander TG, Kharazmi A 1996. Evaluation of the polymerase chain reaction in the diagnosis of cutaneous leishmaniasis due to Leishmania major: a comparison with direct microscopy of smears and sections from lesions. Trans R Soc Trop Med Hyg 90: 133-135.

Campanini A, Cíngara A, Saravia N, Arévalo J, Luna C, SosaEstani S, Salomón OD, Segura EL 1993. Caracterización in vitro de aislados de Leishmania de pacientes de Salta. Medicina (Buenos Aires) 53: 81.
Cuba CA, Torno CO, Ledesma O, Visciarelli E, García S, Prat MI, Costmagna R, Barberi L, Evans DA 1996. Human cutaneous leishmaniasis caused by Leishmania (Viannia) braziliensis in Santiago del Estero, Argentina: identification of parasites by monoclonal antibodies and isoenzymes. Rev Inst Med Trop São Paulo 38: 413-421.

De Bruijn MHL, Barker DC 1992. Diagnosis of New World leishmaniasis: specific detection of species of the Leishmania braziliensis complex by amplification of kinetoplast DNA. Acta Trop 52: 45-58.

De Bruijn MHL, Labrada LA, Smyth AJ, Santrich C, Barker DC 1993. A comparative study of diagnosis by the polymerase chain reaction and by current clinical methods using biopsies from Colombian patients with suspected leishmaniosis. Trop Med Parasitol 44: 201-207.

Eresh S, Mc-Callum SM, Barrer D 1994. Identification and diagnosis of Leishmania mexicana complex isolates by polymerase chain reaction. Parasitology 109: 423-433.

Erlich HA, Gelfand D, Sninsky JJ 1991. Recent advances in the polymerase chain reaction. Science 252: 1643-1651.

Fernandes O, Murthy VK, Kurath U, Degrave WM, Campbell DA 1994. Mini-exon gene variation in human pathogenic Leishmania species. Mol Biochem Parasitol 66: 261-271.

Frank FM, Fernández MM, Caffaro CE 2000. Caracterización de la infección por Leishmania spp. en el Chaco salteño: respuesta inmune humoral, infección doble con T. Cruzi y especies de Leishmania involucradas. Medicina (Buenos Aires) 60: 86-87.

Gonzalez AC, Thomas MC, Martínez-Carretero E, Carmelo E, López MC, Valladares B 2004. Molecular and immunological characterization of L14 ribosomal protein from Leishmania braziliensis. Parasitology 128: 139-47.

Laskay T, Mikó TL, Negesse Y, Solbach W, Röllinghoff M, Frommel D 1995. Detection of cutaneous Leishmania infection in paraffin-embedded skin biopsies using the polymerase chain reaction. Trans R Soc Trop Med Hyg 89: 273275.

Lopez M, Inga R, Cangalaya M, Echevarria J, Llanos-Cuentas A, Orrego C, Arévalo J 1993a. Diagnosis of Leishmania using the polymerase chain reaction: a simplified procedure for field work. Am J Trop Med Hyg 49: 348-356.

Lopez M, Inga R, Cueva N, Alvarez E, Arévalo J 1993b. PCR: a tool for diagnosis of american tegumentary leishmaniasis in a health post of rural endemic areas. Archs Inst Pasteur Tunis 70: 499-504.

Marcolongo R, Bellegarde EJ, De Roodt AR, Ruzic AB 1993. Investigación. Departamento Saneamiento Ambiental, Municipalidad de Concepción. Epidemiológica de Leishmaniasis en el Municipio de Concepción. Tucumán, Argentina. Documento Técnico, 36 pp.

Mazza S 1926. Leishmaniasis tegumentaria y visceral. Bol Inst Clín Quir (Buenos Aires) 13: 208-216.

Medeiros ACR, Rodrigues SS, Roselino AMF 2002. Comparison of the specificity of PCR and the histopathological detection of Leishmania for the diagnosis of american cutaneous leishmaniasis. Braz J Med Biol Res 35: 421-424.

Meredith SEO, Zijlstra EE, Schoone GJ, Kroon CCM, Vaneys GJJM, Schaeffer KU, El-Hassan AM, Lawyer PG 1993. 
Development and application of polymerase chain reaction for the detection and identification of Leishmania parasites in clinical material. Arch Inst Pasteur Tunis 70: 419-431.

Piarroux R, Gambarelli F, Dumon H, Fontes M, Dunan S, Mary C, Toga B, Quilici M 1994. Comparison of PCR with direct examination of bone marrow aspiration, myeloculture, and serology for diagnosis of visceral leishmaniasis in inmunocompromised patients. J Clin Microbiol 32: 746749.

Rodgers MR, Popper SJ, Wirth DF 1990. Amplification of kinetoplast DNA as a tool in the detection and diagnosis of Leishmania. Exp Parasitol 71: 267-275.

Rodriguez N, Guzman B, Rodas A, Takiff H, Bloom B, Covit J 1994. Diagnosis of cutaneous leishmaniasis and species discrimination of parasites by PCR and hybridization. J Clin Microbiol 32: 2246-2252.

Safei A, Motazedian MH, Vasei M 2002. Polymerase chain reaction for diagnosis of cutaneous leishmaniasis in histologically positive, suspicious and negative skin biopsies. Dermatology 205: 18-24.

Sambrook J, Fritsch EF, Maniatis T 1989. Molecular cloning: A laboratory manual, 2nd ed., Cold Spring Harbor Laboratory Press, Cold Spring Harbor, US.

Segura EL, Juan N, Piquin AL, Cuba-Cuba CA, Abramo-Orrego
L, McMahon-Pratt D, Montamat EE, Moman H, Grimaldi Jr G 2000. Molecular and biologic characterization of Leishmania parasites implicated in an epidemic outbreak in northwestern Argentina. Parasit Res 86: 504-508.

Sosa-Estani S, Campanini A, Cíngara A, Luna C, Peralta M, Coutada V, Medina L, Riarte A, Salomón OD, Gomez A, Segura EL 1998. Características clínicas y diagnóstico de la Leishmaniasis mucocutánea en pacientes de un área endémica de Salta, Argentina. Medicina (Buenos Aires) 58: 685-691.

Torno-Cafasso O, Visciarelli E, Prat MI, Gracía S, Barbieri G, Suarez L, Ledesma O 1995. Leishmaniasis tegumentaria americana en la provincia de Santiago del Estero, Argentina. Rev As Med Bahía Blanca 1: 20-27.

Villalonga JF 1998. Leishmaniosis. In S Antoni, O Raimondo (eds), Temas de Enfermedades Infecciosas, El Graduado, Tucumán, Argentina, p. 177-190.

Wright DK, Manos MM 1990. Sample preparation from paraffin-embedded tissues. In MA Innis, DH Gelfand, JJ Sninsky, TJ White (eds), PCR Protocols: A Guide to Methods and Applications, Academic Press, New York, p.153.

Yadón ZE 1997. Informe sobre actividades realizadas en la provincia de Tucumán. Brote epidémico de leishmaniasis, INM Dr. Carlos G. Malbrán, Buenos Aires. Documento técnico, $10 \mathrm{pp}$. 